\title{
Market Orientation, Innovativeness and Performance in E-Learning Programme of Sri Lankan Universities
}

\author{
S. Vaikunthavasan ${ }^{1}$ and S. M. A. K. Samarakoon ${ }^{2}$ \\ ${ }^{1}$ Department of Marketing, Faculty of Management Studies and Commerce, \\ University of Jaffna, Sri Lanka \\ Sathana1976@gmail.com
${ }^{2}$ Department of Commerce and Financial Management, Faculty of Commerce and Management, University of Kelaniya, Sri Lanka ajanthasm@yahoo.com

\begin{abstract}
The purpose of the study is to explore the market orientation, innovativeness and performance of the government Universities in Sri Lanka. Sri Lankan Universities were the unit of analysis. Data for this study were collected from the faculty heads or coordinators of Higher education programmmes in government Universities in Sri Lanka. Convenient sampling method was adopted, structured questionnaires were issued directly and sent through the mail to collect data and one hundred and fourteen respondents were gathered in this study. The MARKOR was used to measure the Market Orientation. Correlation and regression analysis were used in order to identify the association among market Orientation, innovativeness and performance. Three market orientation measures included intelligence generation; intelligence dissemination and responsiveness to intelligence were used to investigate their relationships with Innovativeness and performance. All three measures were found to be statistically significant and positively related to the Innovativeness and performance of the course programmes Universities in Sri Lanka. Based on the studies, the Universities were suggested to follow proper market oriented strategy in higher education system, it will lead to optimum performance achievement.
\end{abstract}

Keywords: Innovativeness, Market Orientation, Performance, University 


\section{Research Overview}

Market orientation is a business strategy directed toward employing part of the organization to discover and better serve consumer needs at a profit. 'It implies optimal implementation of business activities and mechanisms that generate, disseminate, and respond to market intelligence pertaining to the consumer '(Kohli, Jaworski \& Kumar, 1993). The empirical results of research (Brettel, Oswald \& Flatten 2012) indicate 'significant relationships between market orientations and market effectiveness and reveal significant interactions between each market orientation fact and the corresponding innovation focus, innovativeness, in turn positively influences business performance'. The quickly changing nature of the uses of technology for teaching and learning must be taken into consideration on e-learning. Sri Lanka higher education system conducts market oriented innovative e-learning study programmes to satisfy the student needs; this growing interest in the concept of market orientation shows that Universities with higher market oriented innovations will obtain better economic and commercial results. It is important to assess the market orientation, innovations leads performance outcome in the existing higher education programmes of the Selected Sri Lankan University.

\section{Background of the Study}

'Market orientation has been characterized as a culture of the organization that requires customer satisfaction be put at the center of business operations and therefore produces superior value for customers and outstanding performance for the firm' (Ihinmoyan \& Akinyele 2010). 'By being market oriented, a firm can keep existing customers satisfied and loyal, attract new customers, accomplish the desired level of growth and market share and, consequently, achieve desirable levels of business performance' (Tsiotsou 2010). 
Higher education is in the leadership position with the use of information and communications technology (ICT) in support of learning, teaching, research and administration in world Universities. In worldwide higher education creates a better learning environment for all learners, wherever and however they study. Its vision is of a world where learners, teachers, researchers and wider institutional stakeholders use technology to enhance the overall educational experience by improving flexibility and creativity and by encouraging comprehensive and diverse personal high-quality learning, teaching and research.

E-learning is taking into account the connectivity with information and people. E-learning can be seen as both a result of rapid technological change and a response to the changes happening in culture and society. Assessment of student learning and evaluation of instruction are of critical importance and can and need to be supported by e-learning technology and strategies. 'Study from an innovation adoption perspective investigates Chinese students' intentions for taking up e-learning degrees in higher education' (Duan et al 2010). 'Selecting a suitable institute is not an easy task, as 'educational institutes' continue to mushroom in every nook and corner, and the print media is laden with their advertisements. Identifying the determinants of selecting a particular educational institute and measuring its relative importance varies from one student to the other'(Ratnaweera, 2014).

'Karunanayake agreed in the Sunday times that certain local universities are already ready for international students, but he stressed: I believe that they need to understand the requirements of a fee-paying international student and his or her expectations, it is known that Sri Lankan universities are not very student centric, and this change will have to take place at the core of an institution before it can attract foreign students '(Market Snapshot: Sri Lanka, 2013). 


\section{Statement of the Research Problem}

A significant body of research is focused on the conceptualization of market orientation showing evidence of a relationship between market orientation and business performance. There are many researches regarding MO, innovativeness and performance in world wide. Despite there are many researches regarding MO, innovativeness and performance in manufacturing sector in Sri Lanka , only few researcher were conducted in service sector, Keeping track of limited research in service sector in Sri Lanka on this issue, this study attempts to investigate the effect of market orientation and innovation on the performance in service sector. While evidence of the relationship of $\mathrm{MO}$, innovation and performance have been established in the education system in other foreign countries, no such relationship has been investigated in Sri Lankan higher education system. 'Yet, the results of extensive review of related literature studies have been mixed and contradictory' as evidenced by research by Tsiotsou \& Vlachopoulo (2011). "Still not enough is known about the impact of 'Market orientation' on performance when innovation is taken into account in the education sector. In this study researcher is try to espouse the impact and relationships of MO, Innovation and performance in higher education e-learning programme of Sri Lankan Universities.

\subsection{Research Question}

The following the research question was developed in this study:

What is the empirical association between market orientation, innovation and performance outcome within e-learning program?

\section{Objectives of Study}

This research has following objectives related with the e-learning system in Sri Lankan universities: 
- To identify the impact between market orientation on innovativeness

- To examine the impact of market orientation on performance

- To diagnose the impact of innovativeness on performance

\section{Literature Review}

\subsection{Market Orientation}

Liu, Luo and Shi (2002) expressed that Market orientation has been characterized as a culture of the organization that requires customer satisfaction be put at the center of business operations and therefore produces superior value for customers and outstanding performance for the firm( Ihinmoyan \& Akinyele 2010). Customer needs and expectations evolve over time and delivering consistently high quality products and services and responsiveness to changing marketplace needs become important for the success of firms (Ihinmoyan \& Akinyele 2010). Responsiveness to changing market needs often calls for the introduction of new products and services together with innovation capacity for a firm. Market orientation has also been described as the implementation of marketing activities designed to satisfy customer needs better than competitors are able to satisfy customer needs.

Kohli and Jaworski (1990) defines market orientation as the organizationwide generation of market intelligence pertaining to current and future needs of customers, dissemination of intelligence within an organization and responsiveness to it. These authors therefore define this concept through three basic components activities / processes dealing with marketing information:

- intelligence generation,

- intelligence dissemination and

- responsiveness 
A new perspective for viewing marketing orientation concept has emerged within the marketing literature. In this context, Shapiro,Kohli, Jaworski, Narver and Slater, Ruekert and Deshpande et al explored five different perspectives, have been advanced that visualized market orientation as the implementation of marketing concept(Zebal,2003). These are:

- decision-making perspective,

- market intelligence perspective,

- culturally based behavioural perspective,

- strategic perspective, and

- the customer orientation perspective

Narver and Slater (1990) proposed a slightly different definition, market orientation as the organizational culture that most effectively and efficiently creates the necessary behaviours for the creation of superior value for buyers and thus superior performance for business (Kolar 2010). These authors define three basic components of the construct as:

- customer orientation,

- competitor orientation and

- inter-functional coordination.

\subsection{Innovativeness}

An innovation is defined as an idea or object that is perceived as new by an individual or an agency (Rogers, 1995) "The perceived newness of the idea from the individual's point of view determines his or her reaction to it. If the idea seems new to the individual, it is an innovation" (Ihinmoyan,\& Akinyele, 2010). Tyler, (2001) expressed that an innovation consists of certain technical knowledge about how the things can be done better than existing state of the art (Ihinmoyan, \&Akinyele, 2010). 
Garcia \& Calantone( 2002) put forward that Innovativeness is a measure of the degree of newness of a new product, service or idea. Therefore this term is used to refer to the degree of newness or novelty, and they asserted that highly innovative products are seen as having a high degree of newness and low innovative products sit at the opposite extreme of the continuum (Semasinghe 2011).

The term innovativeness can refer to products/services as well as individuals or organizations. Ali (2000) refers to innovativeness as the degree of "newness" of a product and also Rogers (1995) considers it as the degree to which an individual or organization adopts new ideas earlier than others (Han et al 2013). As an organizational culture, innovativeness is a measure of the organization's orientation toward innovation.

\subsection{Performance}

Performance outcome is a statement of a result. It is a management tool used to clarify goals, document the contribution toward achieving those goals, and document the benefits of the program and the services to customers. An outcome is something that is measureable and data collection is part of the process and it is specific result that the firm is seeking. Indicators are the specific data that tracks the client's success. An indicator or benchmark is a measure, for which data is available, which helps quantify the achievement of an outcome. Performance Measure is the method used to measure progress. It indicates what the program is accomplishing and if the results are being achieved, the outcome measures should be characterized as measureable, obtainable, understandable, clear, accurately reflecting the expected result, and set at a level to be attained within a specific time frame. Once the measures have been selected, it is necessary to design a way to get the information (Lehigh country 2014). 
Three hundred randomly chosen faculty members of a southwestern U.S. university were invited to participate in voluntary field surveys over an eight month period Organization. Performance Was indirectly measured three dimensions of organization performance - (1) overall performance, (2) retention and recruiting, and (3) fund raising and grant generation in University(Niculescu, Xu, Hampton, \& Peterson 2013).

In order to capture the multi-dimensionality of performance Chakravarthy, Venkatraman and Ramanujan (1986), asserted that performance is divided into two dimensions:

- Market performance and

- Financial performance.

\section{Methodology}

Researcher followed the quantitative methodology and conduct deductive research approach. There are fifteen universities with different stream programmes. Universities are conducting free courses and payment courses. Most of University course are combined with the e-learning education mode. All e-learning collaborated of higher education programmes from Sri Lankan Universities are the population for the study. It was unable to access all elearning collaborated of higher education programmes from Sri Lankan Universities. Convenient sampling selection was utilized for this data gathering purpose. Altogether one hundred and fourteen programmes were collected for this research (University of Colombo - 45, University of Kelaniya-18, University of Jaffan-51).

Sri Lankan Universities were the unit of analysis. Data collections are carried out from the department or faculties and it is denoted that unit of analysis is the department or faculty. To measure the construct related to the subjects of the 
study it is vital to collect data from heads of department or coordinators of faculties as the elements of target population. So the sample of elements of this study is heads of department or coordinators of faculties.

A structured questionnaire survey was issued to obtain data about the market orientation, innovation and performance of the management stream courses with e- learning program. Pilot study was conducted and survey instrument was modified based on academic experience and suggestions of respondents. These questionnaires were issued through the mail and directly to responsible person of e-learning programmes at selected Universities. Researcher conducted reliability test, validity test, correlation analysis and regression analysis using SPSS 21 version.

\section{Conceptual framework}

There are three components in this survey as marketing orientation, innovativeness and performance: Market orientation is an independent variable which is measured through Intelligence generation, Dissemination of the intelligence and Responsiveness to the intelligence whereas innovation and performance are dependent variables (Kohli and Jaworski 1990). Schumpeter (1982) identified following types of innovations, they are products, process, the exploitation of the market and new ways to organize business. Researcher utilized the three-item for the performance measurement by referring the Niculescu, Xu, Hampton, \& Peterson (2013), which examines Overall Performance, Funding and Retention. Figure 1 explores the relationship between the independent and dependent variables. 


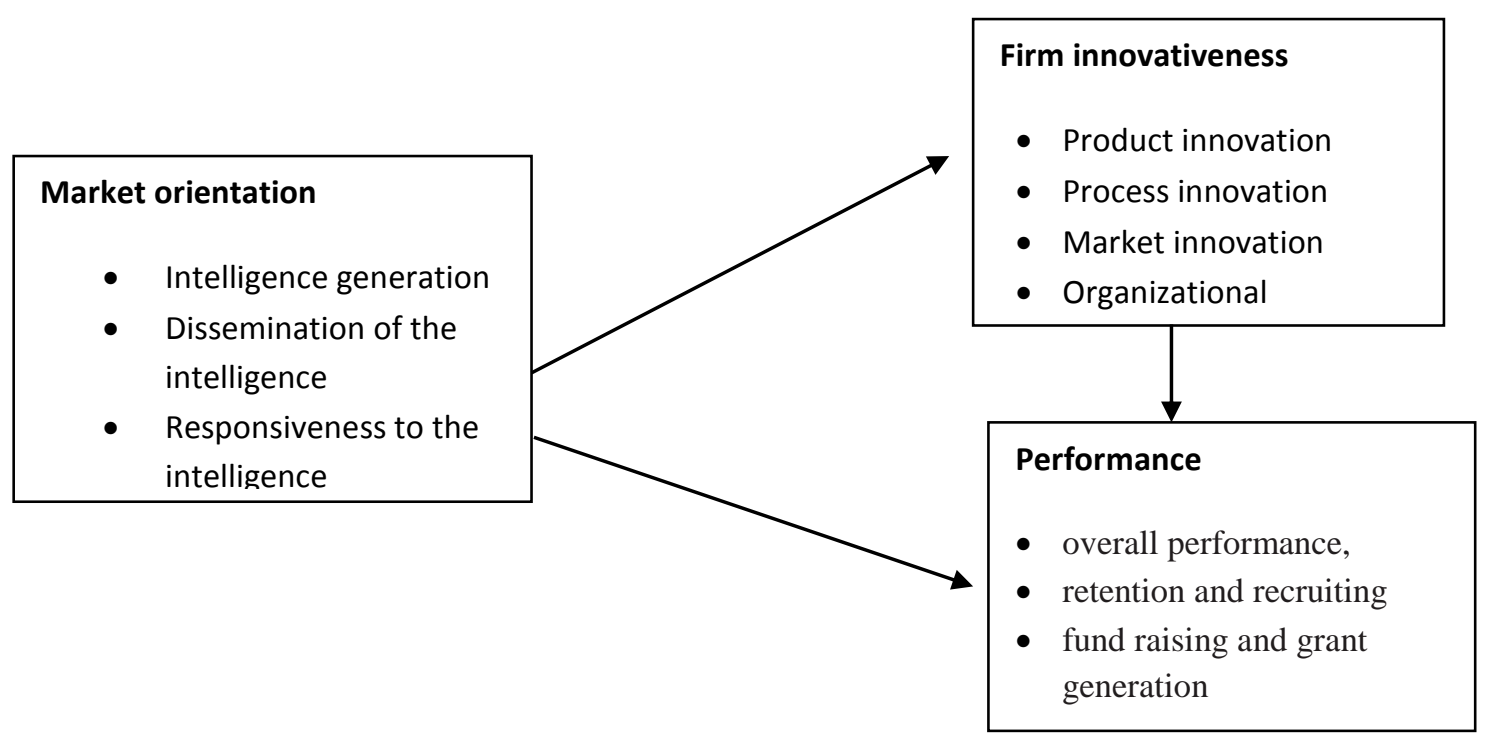

\section{Figure 1: Conceptualization Model}

Source: Developed by researcher based on study of Jaworshi \& Kohli (1993) and Erdil, Erdil, \& Keskin (2010)

\section{Hypotheses}

According to the view of authors and researchers market orientation (MO) is an important ancestor of innovativeness. The following hypothesis were proposed in this survey

H1: Market orientation is positively associated with a firm's innovativeness.

$\mathrm{H} 1 \mathrm{a}$ : There is a positive relationship between the intelligence generation (IG) and innovativeness.

$\mathrm{H}$ 1b: There is a positive relationship between the intelligence dissemination (ID) and innovativeness.

$\mathrm{H}$ 1c: There is a positive relationship between the Responsiveness to the intelligence (RI) and innovativeness.

Compelling evidence in the literature supports a linkage between market orientation and performance, therefore, it is hypothesized that: 
$\mathrm{H}$ 2: There is a positive association between market orientation and performance.

H2a: Intelligence generation and performance are positively correlated

$\mathrm{H} 2 \mathrm{~b}$ : Intelligence dissemination and performance are positively correlated

H2c: Responsiveness to the intelligence and performance are positively correlated

The researches show innovativeness and performance relationship. Researcher hypothesizes:

H3: Innovativeness positively impact on performance

\section{Measurement model}

\subsection{Reliability of scale}

According to Nalluly (1978) the alpha scale should be greater than 0.70 for the items used in this survey and Hire et al. (1998) also suggest that the generally agreed upon the lower limit for Cronbach's alpha is 0.7 Shivani (2010). The value of alpha for each constructs is above 0.7 , indicating high reliability of the construct. The following table 1 indicates all reliability statistic of construct of MO, innovativeness and performance which are above 0.7 and high reliability of items.

Table 1: Reliability statistic of "MO"

\begin{tabular}{lc}
\hline Data & Cronbranch's alpha \\
\hline Information Generation & 0.795 \\
\hline Intelligence Dissemination & 0.760 \\
\hline Responsiveness to intelligence & 0.781 \\
\hline Innovativeness & 0.762 \\
\hline Performance & 0.779 \\
\hline
\end{tabular}

Source: Survey data, 2014 


\subsection{Sample adequacy test}

The reliability measure also covered the sample adequacy test, the minimum acceptable value of KMO as supported by Othman and owen (0.5). The Kaiser-Meyer- Olkin measures were constructed for checking out the sample adequacy of research. The Kaiser-Meyer-Olkin Measure of Sampling Adequacy is a statistic that indicates the proportion of variance in variables that might be caused by underlying factors. High values (close to 1.0) generally indicate that a factor analysis may be useful with your data Malhotra, \& Dash (2011).

\section{Table 2: KMO and Bartlett'e Test}

\begin{tabular}{|l|l|l|}
\hline \multicolumn{2}{|l|}{ KMO measures of Sample Adequacy } & 0.764 \\
\hline \multirow{3}{*}{ Bartlett'e Test of sphericity } & Approximate Chi-Square & 295.455 \\
\cline { 2 - 3 } & DF & 3 \\
\cline { 2 - 3 } & Sig & 0.000 \\
\hline
\end{tabular}

Source: Survey data, 2014

Altogether one hundred and fourteen programmes were collected by the researcher. The value of KMO came out to be 0.764 (Table 2) indicating the factor analysis test can be proceeded correctly and the sample used is adequate the minimum acceptable value of KMO as supports by Othman and Owen (0.5).

\subsection{Validity of Scales}

As can be seen in the table above and KMO and Bartlett's test of spherity indicated the significant of validity regarding the variable as the significant value is 0.000 .

In the marketing literature, several scales have been used to measure market orientation. Among them, two basic approaches to the operationalization of market orientation can be identified. Researcher utilized a questionnaire 
designed by Kohli and Jaworski (1990) to measure the market orientation this has been found to be valid and reliable. The approach MARKOR was represented by Kohli and Jaworski (1990) and Kohli, Jaworski, and Kumar (1993), who defined market orientation as the implementation of the marketing concept, composing of organization-wide generation of market intelligence, the dissemination of that information across departments, and the organization-wide responsiveness to such information. This famous model of MO was applied in the survey of Fairrell, and Oczkowski (2002).

Researcher identified high validity in the MO model adapted to this study. The questionnaire consists of 23 items, yielding a score for each of the nine components of their definition of market orientation, and an overall market orientation score. Each item was presented as a statement representing the ideal behavior of a market-oriented University. A scale from 0 to 7 was used for these items, where 7 indicated that the statement "strongly agree of the firm, 1 "strongly disagree. This measurement model was used by Niculescu, et al (2013), in the survey of market orientation and its measurement in Universities. For the innovativeness measurements researcher utilized the scale developed in the fourth community innovation survey, this model also suggested by Gamal, Salah, \& Elrayyes (2011) in his research . This is a Likert scale comprising four items. A seven-point scoring format was employed for these items.

University performance was measured into three dimensions as overall performance, retention and recruiting, and fund raising and grant generation - via a 10 item seven-point Likert scale. This measurement model was used by Niculescu, et al (2013), in the survey of market orientation and its measurement in Universities. 


\subsection{Inferential statistical analysis of the data}

The research problem of the study was "what are the empirical associations among market orientation, innovation and performance outcome?"

Table 3: Correlation and Regression coefficient of Mo and Innovativeness

\begin{tabular}{|l|l|}
\hline \multicolumn{1}{|c|}{$\begin{array}{c}\text { Independent variable: } \\
\text { MO }\end{array}$} & \multicolumn{1}{c|}{ Dependent variable: Innovativeness } \\
\hline $\mathrm{R}$ & $\begin{array}{l}0.851^{* *}(* * . \text { Correlation is significant at the } 0.01 \\
\text { level (2-tailed)) }\end{array}$ \\
\hline Significance of $\mathrm{F}$ & 0.000 \\
\hline Adjusted $\mathrm{R}^{2}$ & 0.722 \\
\hline
\end{tabular}

Source: Survey data, 2014

H1: Market orientation is positively associated with a firm's innovativeness

The above table 3 illustrates that the beta value between market orientation and innovativeness is 0.851 . So there is high positive significant correlation between the market orientation and innovativeness at 0.01 levels. The adjusted $\mathrm{R}^{2}$ is 0.722 , it reveals the $72.2 \%$ of the variance in innovativeness is accounted by the market orientation. The market orientation is positively impact on the innovativeness. Considering the above facts, the hypothesis 1 is proved and there is evidence of greater market orientations encounter for the innovativeness in the education.

Table 4: Correlation and Regression coefficient of IG and Innovativeness

\begin{tabular}{|l|l|}
\hline \multicolumn{1}{|c|}{$\begin{array}{c}\text { Independent variable } \\
: I G\end{array}$} & \multicolumn{1}{c|}{ Dependent variable: Innovativeness } \\
\hline $\mathrm{R}$ & $\begin{array}{l}0.802 * * \text { Correlation is significant at the } 0.01 \text { level } \\
(2 \text {-tailed). }\end{array}$ \\
\hline Significance of $\mathrm{F}$ & 0.000 \\
\hline Adjusted $\mathrm{R}^{2}$ & 0.640 \\
\hline
\end{tabular}

Source: Survey data, 2014 
$\mathrm{H} 1 \mathrm{a}$ : There is a positive relationship between the intelligence generation and innovativeness

The above table 4 indicated that intelligence generation found to have significant positive relationship with innovativeness $(\mathrm{R}=.802$; significant at $0.000)$. The adjusted $\mathrm{R}^{2}$ is $0.640(\mathrm{p}<.01)$, It explains the $64 \%$ of innovativeness is explained by the intelligence generation. All the above explanation reveals that the hypothesis 1a is proved, and there is evident of greater association between the intelligence generation and innovativeness.

\section{Table 5: Correlation and Regression coefficient ID and Innovativeness}

\begin{tabular}{|l|l|}
\hline $\begin{array}{c}\text { Independent variable } \\
\text { :ID }\end{array}$ & \multicolumn{1}{|c|}{ Dependent variable: Innovativeness } \\
\hline $\mathrm{R}$ & $\begin{array}{l}0.751^{* *} \text { Correlation is significant at the } 0.01 \text { level } \\
(2 \text {-tailed) }\end{array}$ \\
\hline Significance of $\mathrm{F}$ & 0.000 \\
\hline Adjusted $\mathrm{R}^{2}$ & 0.561 \\
\hline
\end{tabular}

Source: Survey data, 2014

$\mathrm{H} 1 \mathrm{~b}$ : There is a positive relationship between the intelligence dissemination and innovativeness

According to the above table 5 the correlation coefficient between intelligence dissemination and innovativeness is $0.751(\mathrm{P}<0.01)$. This result reveals the significant high positive relationship between intelligence dissemination and innovativeness. The adjusted $\mathrm{R}^{2}$ is 0.561 , it explains $56.1 \%$ of innovativeness is encountered by the intelligence dissemination at significant of 0.000 value. The significant value reveals there is significant impact of intelligence dissemination on innovativeness. Hence the hypothesis $1 \mathrm{~b}$ is proved by this analysis. 
Table 6: Correlation and Regression coefficient RI and innovativeness

\begin{tabular}{|l|l|}
\hline $\begin{array}{c}\text { Independent variable } \\
: \mathbf{R I}\end{array}$ & \multicolumn{1}{c|}{ Dependent variable: Innovation } \\
\hline $\mathrm{R}$ & $\begin{array}{l}0.660^{* *} \text {. Correlation is significant at the } 0.01 \text { level } \\
(2 \text {-tailed }) .\end{array}$ \\
\hline Significance of $\mathrm{F}$ & 0.000 \\
\hline Adjusted $\mathrm{R}^{2}$ & 0.430 \\
\hline
\end{tabular}

Source: Survey data, 2014

$\mathrm{H} \mathrm{1c:}$ There is a positive relationship between the responsiveness to the intelligence and innovativeness.

Above table 6 indicates the correlation coefficient of responsiveness to intelligence and innovativeness is $0.660(\mathrm{p}<0.01)$, there is significant positive correlation between responsiveness to intelligence and innovativeness. The adjusted $\mathrm{R}^{2}$ is $0.430(\mathrm{P}<0.01)$, these information indicates that the $43 \%$ changes in the innovativeness is encountered by responsiveness to intelligence and this regression model is satisfactory fit to the data. It has been noted that fitted model revealed the significant relationship between responsiveness to intelligence and innovativeness, accuracy of the predictability of the fitted model is high. So the hypothesis $1 \mathrm{c}$ is proved and accepted.

Table 7: Correlation and Regression coefficient Mo and performance

\begin{tabular}{|l|l|}
\hline $\begin{array}{c}\text { Independent variable } \\
\text { :MO }\end{array}$ & \multicolumn{1}{c|}{ Dependent variable: $\mathbf{P}$} \\
\hline $\mathrm{R}$ & $\begin{array}{l}0.849 * * . \text { Correlation is significant at the } 0.01 \text { level } \\
(2 \text {-tailed }) .\end{array}$ \\
\hline Significance of $\mathrm{F}$ & 0.000 \\
\hline Adjusted $\mathrm{R}^{2}$ & 0.718 \\
\hline
\end{tabular}

Source: Survey data, 2014 
$\mathrm{H} 2$ : There is a positive association between market orientation and performance.

According to the table 7 the between correlation value for market orientation and performance is 0.849 , there is the correlation value with two asterisk at the 0.01 level. These indicate that there is significant high positive correlation between the market orientation and performance. The adjusted $\mathrm{R}^{2}$ is 0.718 for market orientation and performance, $71.8 \%$ of performance is influenced by the market orientation; this regression model fit is very high at the significance of 0.000 values. The accuracy of the dependent variable is predicted by the independent variable properly. The model fit, impact, and market orientation influence on performance is uniquely agreed. So the hypothesis 2 is proved with adequate evidence.

\section{Table 8: Correlation and Regression coefficient IG and Performance}

\begin{tabular}{|l|l|}
\hline \multicolumn{1}{|c|}{$\begin{array}{c}\text { Independent } \\
\text { variable :IG }\end{array}$} & \multicolumn{1}{|c|}{ Dependent variable: performance } \\
\hline $\mathrm{R}$ & $\begin{array}{l}0.764^{* *} \text {. Correlation is significant at the } 0.01 \\
\text { level (2-tailed). }\end{array}$ \\
\hline Significance of $\mathrm{F}$ & 0.000 \\
\hline Adjusted $\mathrm{R}^{2}$ & 0.580 \\
\hline
\end{tabular}

Source: Survey data, 2014

H2a: Intelligence generation and performance are positively correlated

Above table 8 reveals the correlation value as $0.764(\mathrm{p}<0.01)$. There is high positive significant correlation between intelligence generation and performance. The correlation is high significant at the 0.01 level, the adjusted $\mathrm{R}^{2}$ value is 0.580 of intelligence generation and performance. this indicates that the $58 \%(\mathrm{p}<0.01)$ of the performance is associated with intelligence generation, the intelligence generation is predicted as an important variable for performance, there is significant impact of intelligence generation on performance and 
significant regression model fit, accurate predictor for dependent variable. So the hypothesis $2 \mathrm{a}$ is proved.

Table 9: Correlation and Regression coefficient ID and Performance

\begin{tabular}{|l|l|}
\hline $\begin{array}{c}\text { Independent variable } \\
\text { :ID }\end{array}$ & \multicolumn{1}{c|}{ Dependent variable: performance } \\
\hline $\mathrm{R}$ & $\begin{array}{l}0.762^{* *} \text {. Correlation is significant at the } 0.01 \text { level } \\
(2 \text {-tailed). }\end{array}$ \\
\hline Significance of $\mathrm{F}$ & 0.000 \\
\hline Adjusted $\mathrm{R}^{2}$ & 0.577 \\
\hline
\end{tabular}

Source: Survey data, 2014

$\mathrm{H} 2 \mathrm{~b}$ : Intelligence dissemination and performance are positively correlated

In the above table 9 the correlation coefficient between the intelligence dissemination and $\mathrm{R}$ is 0.762 and significance ( 2 tailed) value is 0.000 . There is significant high positive correlation between the intelligence dissemination and performance. The adjusted $\mathrm{R}^{2}$ is $0.577,57.7 \%$ of performance is encountered by ID, it is significantly and accurately fitted model for by the significant value of 0.000 , further beta value explains the ID is the major predicator for the performance. So the hypothesis $\mathrm{H} 2 \mathrm{~b}$ is proved and accepted.

Table 10: Correlation and Regression coefficient RI and performance

\begin{tabular}{|l|l|}
\hline \multicolumn{1}{|c|}{$\begin{array}{c}\text { Independent } \\
\text { variable }: \mathbf{R I}\end{array}$} & \multicolumn{1}{|c|}{ Dependent variable: performance } \\
\hline $\mathrm{R}$ & $\begin{array}{l}0.688^{* *} \text {. Correlation is significant at the } 0.01 \text { level } \\
(2 \text {-tailed). }\end{array}$ \\
\hline Significance of $\mathrm{F}$ & 0.000 \\
\hline Adjusted $\mathrm{R}^{2}$ & 0.469 \\
\hline
\end{tabular}

Source: Survey data, 2014 
$\mathrm{H} 2 \mathrm{c}$ : Responsiveness to the intelligence and performance are positively correlated

According to the above table 3 the $\mathrm{R}$ is 0.688 (Correlation is significant at the 0.01 level 2-tailed). There is high positive significant correlation between responsiveness to intelligence and performance. The adjusted $\mathrm{R}^{2}$ is 0.469 , so the 46.9 of performance is encountered by the responsiveness to intelligence. There is accurate model fit ensured by the 0.000 significance value. Beta value also explains the predictor is perfectly correlated with independent variable. So the hypothesis $\mathrm{H} 2 \mathrm{c}$ was proved.

Table 11: Correlation and Regression coefficient Innovativeness and performance

\begin{tabular}{|l|l|}
\hline \multicolumn{1}{|c|}{$\begin{array}{c}\text { Independent variable } \\
\text { :innovativeness }\end{array}$} & \multicolumn{1}{c|}{ Dependent variable: performance } \\
\hline $\mathrm{R}$ & $\begin{array}{l}0.688^{* *} \text {. Correlation is significant at the } 0.01 \\
\text { level (2-tailed). }\end{array}$ \\
\hline Significance of $\mathrm{F}$ & 0.000 \\
\hline Adjusted $\mathrm{R}^{2}$ & 0.469 \\
\hline
\end{tabular}

Source: Survey data, 2014

H3: Innovativeness positively impact on performance

Above table 11 addresses the $\mathrm{R}$ value as $0.807(\mathrm{p}<0.01)$. There is positive significant correlation between innovativeness and performance. The correlation is high significant at the 0.01 level, the adjusted $\mathrm{R}^{2}$ value is 0.648 of innovativeness and performance. this indicates that the $64.8 \%(\mathrm{p}<0.01)$ of the performance is associated with innovativeness, the innovativeness is predicted as an important variable for performance, there is significant impact of innovativeness on performance and significant regression model fit, accurate predictor for dependent variable. So the hypothesis 3 is proved. 


\section{Conclusion and Recommendations}

This study has examined the MO, innovativeness and performance. The measures were conducted in higher education programmes of Sri Lankan Universities. For this study the population was fifteen University higher education programmes, the sample was 114 programmes from three Universities. Researcher utilized valuable measurement models in this study. MAKROR model of Kohli and Jaworski (1990) was adopted for measuring MO and innovativeness measurement model was adopted the model introduced by the Schumpeter (1982), the performance measurement model was retrieved from the Niculescu, Xu, Hampton, \& Peterson (2013). Further three variables were rated with 7 point likert scale system, it ensure high reliability of scale measurements. Researcher utilized factor analysis to test the reliability and validity of construct used in this study. Cronbranch's Alpha methods were used for calculating internal consistency. The value of alpha for each constructs regarding MO, innovativeness and performance are 0.757 , indicated high reliability of the construct. The result form the analysis, KMO and Bartlett's test of spherity indicated the significant of validity regarding the variable as the significant value is 0.000 .

The result reveals there were significant positive relationship and impact of intelligence generation, intelligence dissemination and responsiveness to intelligence on the Innovativeness. So the Hypotheses "Market orientation is positively associated with a firm's (H1), there is a positive relationship between the intelligence generation and innovation (H1a), there is a positive relationship between the intelligence dissemination and innovation ( $\mathrm{H} 1 \mathrm{~b})$ and there is a positive relationship between the responsiveness to the intelligence and innovation (H1c) were proved with this model1. The hypotheses "there is a positive association between market orientation and performance (H2), intelligence generation and performance are positively correlated (H2a), 
intelligence dissemination and performance are positively correlated $(\mathrm{H} 2 \mathrm{~b})$ and responsiveness to the intelligence and performance are positively correlated (H2c)" were proved. The result reveals the positive effect of innovativeness on performance. So the hypothesis 3 "innovativeness positively impact on performance was proved.

Researcher recommended with this survey experience, the Universities were suggested to follow proper market oriented strategy in higher education system, it will lead to optimum performance achievement, further market oriented in education is highly related with e-learning collaborated education system. It was identified that most of the students prefer to follow the e-learning collaborated programmes that means higher demand for these programmes. Under the University education system, there must be standardized innovative elearning programmes. This being the case, market orientation scales must be assessed in other higher education-related private and government contexts. Future studies could use MKTOR model to analyze responses to market orientation within and between universities, and at the same time producing higher response rates and bigger sample sizes. Another research route could focus on measuring the impact of market orientation in universities with respondents of not only the heads or coordinators but also all academics of the course programmes.

\section{References}

Brettel,M. , Oswald,M. \& Flatten,T. (2012). Alignment of market orientation and innovation as a success factor: a five-country study, Technology Analysis \& Strategic Management, 24:2, 151-165, DOI: $10.1080 / 09537325.2012 .647640$

Chakravarthy, B. S. (1986). Measuring strategic performance. Strategic Management

Deshpandé, R. \& Farley, J.U. (1996). Understanding Market Orientation: A Prospectively Designed Meta-analysis of Three Market Orientation 
Scales. Working Paper 96-125, Cambridge, Massachusetts: Marketing Science Institute.

Deshpandé, R. and Webster, J. (1989) Organizational culture and marketing: defining the research agenda. Journal of Marketing 53.

Duan, Y., He, Q., Feng, W., Li, D., \& Fu, Z. (2010). A study on e-learning takeup intention from an innovation adoption perspective: A case in China. Computers \& Education, 55, 237-246.

Education in Sri Lanka. (2014). Retrieved from http://en.wikipedia.org/

Erdil,S., \& Erdil ,O., \& Keskin,H.(2010), The relationships between market orientation, firm innovativeness and innovation performance, Journal of Global Business and Technology,

Farrell. \& Oczkowski. (1997). An Analysis of the MKTOR and MARKOR Measures of Market Orientation: An Australian Perspective, Marketing Bulletin, 3(8), 30-40.

Gamal,D., .Salah,T., \& Elrayyes, N.(2011). How to Measure Organization Innovativeness, an Overview of innovation measurements frameworks and Innovation Audit/Management Tools,

Han,X., Hansen,E., Rajat Panwar, Rebecca Hamner., \& Nadine Orozco. (2013). Connecting market orientation, learning orientation and corporate social responsibility implementation: is innovativeness a mediator?, Scandinavian Journal of Forest Research, 28(8), 784-796, DOI: 10.1080/02827581.2013.833290 http://dx.doi.org/10.1080/02827581.2013.833290

Higher Education Commission, Comparative education. (2012). Retrieved from http://www.hec.gov.pk/

Hurley, R.F. \& Hult, G.T.M. (1998), Innovation, Market Orientation and Organizational Learning: An Integration and Empirical Examination, Journal of Marketing, 62, 42-54. 
Ihinmoyan, T. \& Akinyele, S.T. (2010). Relationship between market orientation, firm innovativeness and innovative performance.

Jaworski, B.J., \& Kohli, A.K. (1993). Market orientation antecedents and consequences. Journal of Marketing. 57, 53-70.

Jaworski, B.J., Kohli, A.K., \& Sahay, A. (2000). Market-driven versus driving markets. Journal of the Academy of Marketing Science 28(1), 119-35

Kohli A. and Jaworski B.J. (1990), "Market Orientation: The Construct, Research Propositions and Managerial Implications" Journal of Marketing Research, 54. 1-19.

Kohli. A.J. Jaworski. B.J. \& Kumar .A. (1993). MARKOR: A Measure of Market Orientation Journal of Marketing Research, 30(4), 15-19. American Marketing Association: http://www.jstor.org/stable/3172691 Accessed: 03/03/2010

Kolar .T (2010), Development of Market Orientation in a Services Context - An Alternative Model Proposal

Kotler,P., Keller,K.L. , Koshy,A. and Mithileshwar. (2012). Marketing Management. $14^{\text {th }}$ Edition, Prentice Hall

Kwaku Atuahene-Gima, K. (1995). An exploratory analysis of the impact of market orientation on new product performance a contingency approach. Journal of Product Innovation Management 12(4), 275-293.

Literature Review on E-Education. Study Mode.com (2010), Retrieved from http://www.sudymode.com/essays/literature-Review-on-e-Education$4125 \mathrm{html}$

Liu, S.S., Luo, X., \& Shi, Y. (2002). Integrating Customer Orientation in Organizations -in- Transition: An Empirical Study, International Journal of Research in Marketing, 19, 367-382.

Market Snapshot: Sri Lanka (2013), ICEF Monitor, Retrieved fromhttp://sbmonitor-3.icef.com/2013/10/market-snapshot-sri-lanka/ 
Malhotra,N.K.,\& Dash,S. (2011). Marketing research: An Applied orientation, Sixth Edition, Pearson: Prentice Hall

Ministry of Higher Education. (2014). Retrieved from http://www.mohe.gov.lk/

Modi,P., (2012). Market orientation in nonprofit organizations: innovativeness, resource scarcity, and performance, Journal of Strategic Marketing, 20(1), 55-67, DOI: 10.1080/0965254X.2011.628405 To link to this article http://dx.doi.org/10.1080/0965254X.2011.628405

Mostaque Ahmed Zebal David R. Goodwin, (2012), Market orientation and performance in private

Narver, J.C., Slater, F.S., \& Tietje, B. (1998). Creating a market orientation. Journal of Market focused Management 2(3), 241- 55

Narver, J.C., \& Slater, S.F., (1990) "The Effect of Market Orientation on Business Profitability”, Journal of Marketing, 20-35.

Niculescu., Xu., Hampton., \& Peterson. (2013). Market Orientation and Its Measurement in Universities, Journal: education, practice and research 3 (2) Doi: $10.5929 / 2013.3 .2 .2$

Ratnaweera.U reports on TNS Lanka's exclusive education survey (2014), Retrieved from http://lmd.lk/2013/09/01/2279/

Rogers, E.M. (1995). Diffusion of innovations, $4^{\text {th }}$ ed. Free press, NY.

Ruekert, R.W. (1992). Developing a market orientation Rodolfo: an organisational strategy perspective. International Journal of Research in Marketing 9, 225- 45.

Samuelsson, M. \& Davidsson,P. (2009). Does Venture Opportunity Variation Matter? Investigating Systematic Process Differences between innovative and imitative new ventures. Small Business Economics, 33(2), 229.

Schumpeter, J.A. (1934). The Theory of Economic Development .Cambridge: MA: Harvard University press 
Schumpeter,J.A. (1982). The Theory of Economic Development: An Inquiry into Profits, Capital, Credit, Interest, and the Business Cycle (Social Science Classics Series), Transaction Publishers.

Semasinghe D.S. (2011). The Role of Idea Novelty and Relatedness in Nascent Venture

Shivani.S. (2010). Impact of Integrated Mobile Marketing Communications on Customer perceived Value of Services, and the Contribution of Technology as a moderator between them: Special Reference to Private Commercial Banks in Sri Lanka.

Singh,K., \& Weligamage. (2010). Thinking towards Stakeholder Satisfaction in Higher Education: An Application of Performance Prism, university business school, Panjab university, Chandigarh, India, ICBI: university of Kelaniya, Sri Lanka.

Slater, S.F. and Narver, J.C. (2000). Market Oriented is More Than Being Customer-Led, Strategic Management Journal, 20, 1165-8.

Slaver.S.., \& Narver,J.C. (2000). The Positive Effect of a Market Orientation on Business Profitability, Journal of Business Research, 48, 69-73, New York.

Tsiotsou, R.H. (2010). Delineating the effect of market orientation on a component-wise approach, The Service Industries Journal, 30(3), 375403, DOI: $10.1080 / 02642060802236103$, http://dx.doi.org/10.1080/02642060802236103

Tsiotsou, R.H., \& Vlachopoulou,M.. (2011). Understanding the effects of market orientation and e-marketing on service performance, Marketing Intelligence \& Planning, 29(2), 141-155, Emerald Group Publishing Limited.

Tyler,B.B.(2001). The complementary of cooperative and Technological competencies: A resource based perspective, Journal of Engineering Technology Management, 18, 1-27.

UGC, Universities and Institutes, (2014) derived from http://www.ugc.ac.lk/ 
Universities and Institutes. (2014). Retrieved from http://www.ugc.ac.lk/,

Universities, Marketing Intelligence \& Planning, 30(3), 339-357

http://dx.doi.org/10.1108/02634501211226302

Venkatraman, N., \& Ramanujam,V. (1986). Measurement of business performance in strategy research: a comparison of approaches. Academy of Management Review.

Zebal,M.A. (2003). A Synthesis Model of Market Orientation for a Developing Country - The Case of Bangladesh Thesis, http://vuir.vu.edu.au/ 